\title{
PENGARUH MODEL PROBLEM BASED LEARNING (PBL) DISERTAI VIDEO BERBASIS KONTEKSTUAL TERHADAP HASIL BELAJAR DAN KETERAMPILAN PROSES SAINS DALAM PEMBELAJARAN FISIKA DI SMA
}

\author{
${ }^{1)}$ Khantika Andriani, ${ }^{1)}$ Subiki, ${ }^{1)}$ Bambang Supriadi \\ ${ }^{1)}$ Program Studi Pendidikan Fisika FKIP Unervitas Jember \\ Email: khantika.andriani46@gmail.com
}

\begin{abstract}
This study aims to: (1) examine the effect of problem-based learning models and contextual-based videos on student learning outcomes in physics learning in high school (2) to examine the effect of problem-based learning models and contextual-based videos. on students' science process skills in secondary school learning. The researsch model used was true experiment with posttest only control design. The research sample used was class X IPA 2 (experimental class) and X IPA 1 (control class) in SMA Negeri Tamanan. The data obtained included post-test results and science process skills scores. Data analysis was performed with statistics consisting of homogeneity test, normality test, and independent sample t-test. From the independent sample t-test analysis, it was found that it was significant (sig2tailed) of $0,000(0,000 \leq 0.05)$, it can be concluded that Ho was rejected and Ha was accepted that there were differences in student learning outcomes in the experimental class better than the control class. This can be seen from the average posttest score of the experimental class of 72.48 , while the average post-test score of the control class is 48.87 . Based on the results of the analysis of students' science process skills through two experiments, the scores were 76.61 and 77.42 respectively in the very good category. Thus the problem-based learning model accompanied by contextual-based video affects learning outcomes and science process skills of students in high school.
\end{abstract}

Key word: Problem Based Learning, Contextual Video, Physics Learning

\section{PENDAHULUAN}

Pendidikan memiliki peran utama dalam pengembangan personal dan sosial. Selain itu pendidikan juga mempengaruhi perubahan individu, mengubah sikap mental yang kurang. Pendidikan diharuskan mampu menggalakkan inovasi dan mempengaruhi pola serta perilaku masyarakat. Menurut Tirtahardja (2005:85) tujuan pendidikan memuat gambar tentang nilai-nilai yang baik, luhur, pantas, benar dan indah untuk kehidupan.

Fisika merupakan ilmu pengetahuan yang mempelajari gejala-gejala alam melalui serangkaian proses yang dikenal dengan proses ilmiah yang tersusun atas tiga komponen terpenting berupa konsep, prinsip, dan teori yang berlaku secara universal (Trianto, 2010:137-138). Belajar fisika sama halnya dengan belajar hakikat sains yaitu proses dan produk. Hal ini sesuai dengan implementasi kurikulum 2013 yang menuntut peserta didik untuk aktif dalam membangun pengetahuan di dalam proses pembelajaran sehingga peserta didik tidak pasif.

Berdasarkan data dari PUSPENDIK diketahui rata-rata nilai Ujian Nasional (UN) untuk mata pelajaran fisika di Indonesia masih tergolong rendah. Khususnya daerah Bondowoso sendiri, hasil Ujian Nasional dari beberapa sekolah masih dalam kategori kurang. Dari statistik Ujian Nasional mata pelajaran fisika (khusus SMA/MA Negeri di Kabupaten Bondowoso) dari tahun 2016 sampai 2018 

terus mengalami naik turun. Pada tahun 2016 nilai rata-rata Ujian Nasional pada mata pelajaran fisika adalah 41,13 . Pada tahun 2017, nilai rata-ratanya adalah 41,75 sedangkan pada tahun 2018 nilai rata-rata Ujian Nasional pada mata pelajaran fisika adalah 44,23 mengalami penurunan sebesar 2,48. (Puspendik Kemendibud, 2018).

Salah satu model pembelajaran yang dapat melibatkan peserta didik dengan aktif melalui proses penemuan dengan bimbingan guru yaitu model pembelajaran Problem Based Learning (PBL). Model pembelajaran Problem Based Learning (PBL) diharapkan dapat mengembangkan keterampilan proses sains dan hasil belajar fisika peserta didik di SMA yang lebih baik daripada sebelumnya. Hasil belajar disini meliputi kompetensi sikap serta kompetensi pengetahuan sesuai dengan apa yang ada dalam kurikulum 2013.

Menurut Rusman, model Problem Based Learning (PBL) merupakan inovasi dalam pembelajaran karena dalam PBL kemampuan berfikir peserta didik betulbetul dioptimalisasikan melalui proses kerja kelompok atau tim yang sistematis, sehingga peserta didik dapat memberdayakan, mengasah, menguji, dan mengembangkan kemampuan berpikirnya secara berkesinambungan (Rusman, 2012:229).

Media yang bisa dipadukan dengan model pembelajaran Problem Based Learning (PBL) adalah media multimedia. Menurut Eko (2012), media audio-visual (video) memiliki kelebihan dalam ranah kognitif, afektif, dan psikomotor. Kelebihan dalam ranah kognitif antara lain dapat digunakan untuk menunjukkan contoh dan cara bersikap atau berbuat dalam suatu penampilan, khususnya yang menyangkut interaksi peserta didik. Kelebihan dalam ranah afektif antara lain dapat menjadi media yang sangat baik dalam mempengaruhi sikap dan emosi. Kelebihan dalam ranah psikomotor antara lain dapat memperlihatkan contoh keterampilan yang menyangkut gerak, baik dengan cara memperlambat maupun mempercepat gerakan yang ditampilkan.

Berdasarkan permasalahan tersebut, peneliti tertarik untuk meneliti model pembelajaran Problem Based Learning dipadukan dengan media berupa video kejadian fisika diharapkan dapat memberi pengaruh terhadap hasil belajar fisika dan keterampilan proses sains peserta didik. Tujuan dari penelitian adalah untuk meneliti pengaruh model PBL (Problem Based Learning) dan video berbasis kontekstual terhadap hasil belajar dan keterampilan proses sains peserta didik.

\section{METODE PENELITIAN}

Jenis penelitian yang digunakan adalah penelitian true eksperimen dengan desain posttest-only control design. Populasi dalam penelitian adalah seluruh kelas X IPA SMA Negeri Tamanan di Bondowoso tahuan ajaran 2018/2019 yang terdiri dari dua kelas. Teknik pengambilan sampel pada penenelitian ini menggunakan cluster random sampling melalui nilai fisika pada materi sebelumnya. Setelah itu data di uji dengan homogenitas untuk pengambilan sampel kelas eksperimen menggunakan model Problem Based Learning $(P B L)$ disertai video berbasis kontekstual dan kelas kontrol menggunakan pembelajaran yang biasa digunakan guru di sekolah.

Teknik pengumpulan data yang digunakan dalam penelitian ini adalah observasi, keterampilan proses sains dan hasil belajar. Instrumen yang dipersiapkan antara lain lembar observasi, LKS keterampilan proses sains dan hasil belajar kognitif yang diukuur dari nilai post-test yang dilaksanakan setelah pembelajaran berlangsung berupa soal uraian yang terdiri dari 5 soal pada materi getaran harmonis setelah penerapan model Problem Based Learning $(P B L)$ disertai video berbasis kontekstual.

Teknik analisis data hasil belajar menggunakan uji independent sample t-test dengan bantuan SPSS versi-23 yang 
sebelumnya data terlebih dahulu di uji normalitas menggunakan one-samplekolmogorof-smirnov. Sedangkan data keterampilan proses sains melalui teknik observasi dan teknik portofolio menggunakan rumus sebagai berikut: dan

$$
K P S_{\text {obs }}=\frac{\sum \text { skor }}{\sum \text { skor Maks }} \times 100 \%
$$

$$
K P S_{p f}=\frac{\sum \text { skor }}{\sum \text { skor Maks }} \times 100 \%
$$

Keterangan:

KPS = Nilai akhir keterampilan proses

sains

$K P S_{p f}=$ Nilai keterampilan proses sains peserta didik melalui portofolio

$K P S_{o b s}=$ Nilai keterampilan proses sains peserta didik melalui observasi

Dengan kriteria keterampilan proses sains yang terdapat pada tabel 3.4.

Tabel 1. Kriteria Keterampilan Proses Sains Peserta Didik

\begin{tabular}{cc}
\hline Persentase & Kriteria \\
\hline $75 \%<$ skor & Sangat baik \\
$\leq 100 \%$ & \\
$55 \%<$ skor $\leq 75 \%$ & Baik \\
$40 \%<$ skor $\leq 55 \%$ & Cukup baik \\
skor $\leq 40 \%$ & Tidak baik \\
\hline & (Widayanto,2009)
\end{tabular}

\section{HASIL DAN PEMBAHASAN}

Data hasil penelitian peserta didik kelas X IPA SMA Negeri Tamanan di Bondowoso. Kelas $\mathrm{X}$ terdiri dari 2 kelas yaitu X IPA 1 dan X IPA 2. Sebelum melakukan pengambilan sampel, terlebih dahulu dilakukan uji homogenitas menggunakan ANOVA (Analisis of Variance) dengan menggunakan program SPSS versi 23 dari data nilai ujian sebelumnya yaitu pada materi momentum dan implus. Berdasarkan uji homogenitas yang telah dilakukan tersebut diperoleh nilai signifikan sebesar 0,407. Sesuai dengan pedoman pengambilan keputusan pada statistik dapat disimpulkan bahwa nilai signifikan tersebut lebih besar dari tingkat alpha $(\alpha)=5 \%$, yaitu $0,407>0,05$. Dengan demikian kedua kelas tersebut memiliki varian yang sama (homogen). Setelah dihasilkan varian yang sama (homogen), selanjutnya menentukan sampel dengan menggunakan metode cluster random sampling, yaitu menentukan sampel secara acak dengan teknik undian. Sampel penelitian ini adalah satu kelas sebagai kelas eksperimen dan satu kelas sebagai kelas kontrol. Adapun kelas yang menjadi kelas eksperimen yaitu X IPA 2 dan kelas kontrol yaitu X IPA 1. (posttest) yang diperoleh siswa menunjukkan adanya perbedaan antara kelas eksperimen dan kelas kontrol dengan masing-masing jumlah 31 peserta didik untuk kelas eksperimen dan 30 peserta didik untuk kelas kontrol. Kelas eksperimen diberi perlakuan berupa model pembelajaran Problem Based Learning $(P B L)$ disertai video berbasis kontekstual memiliki rata-rata nilai kemampuan kognitif yang lebih baik daripada kelas kontrol yaitu sebesar 72,48 untuk kelas eksperimen sedangkan kelas kontrol hanya memiliki rata-rata sebesar 48,87.

Dari hasil uji normalitas data kemampuan kognitif peserta didik menggunakan Kolmogorov-Smirnov diperoleh nilai Asymp. Sig. (2-tailed) pada kelas eksperimen sebesar 0,063 nilai tersebut lebih besar dari $0,05(0,063>$ $0,05)$. Sedangkan untuk kelas kontrol nilai Asymp. Sig. (2-tailed) sebesar 0,100 nilai tersebut lebih besar dari $0,05(0,100>$ $0,05)$. Hasil tersebut dapat disimpulkan bahwa data yang diperoleh berdistribusi normal, sehingga dapat dilakukan uji independent sample t-test.

Berdasarkan hasil output tabel Leven's Test for Quality of Variance data yang diperoleh dapat dikatakan homogen dengan nilai (Sig.) > dari 0,05, sehingga yang dibaca adalah Equal Variance Assumed. Pada tabel T-Test for Equality of Means pada lajur Equal Variance Assumed menunjukkan bahwa nilai Sig. (2-tailed) 
sebesar $0,000(0,000 \leq 0,05)$. Oleh karena itu dapat disimpulkan bahwa Ho ditolak dan Ha diterima yaitu ada pengaruh signifikan antara hasil belajar fisika peserta didik pada kelas eksperimen dan kelas kontrol atau dengan kata lain model Problem Based Learning (PBL) disertai video berbasis kontekstual berpengaruh signifikan terhadap hasil belajar peserta didik dalam pembelajaran fisika SMA.

Secara statistik, hasil belajar peserta didik antara kelas eksperimen dengan kelas kontrol menunjukkan adanya perbedaan yang signifikan. Perbedaan ini disebabkan karena hasil belajar peserta didik di kelas eksperimen selama melaksanakan proses pembelajaran menggunakan model Problem Based Learning (PBL) disertai video berbasis kontekstual, berbeda dari kelas kontrol yang menggunakan model pembelajaran yang biasa digunakan di sekolah. Hal ini juga dikarenakan pada kelas eksperimen peserta didik memiliki rasa ingin tahu dalam menemukan konsepkonsep fisika.

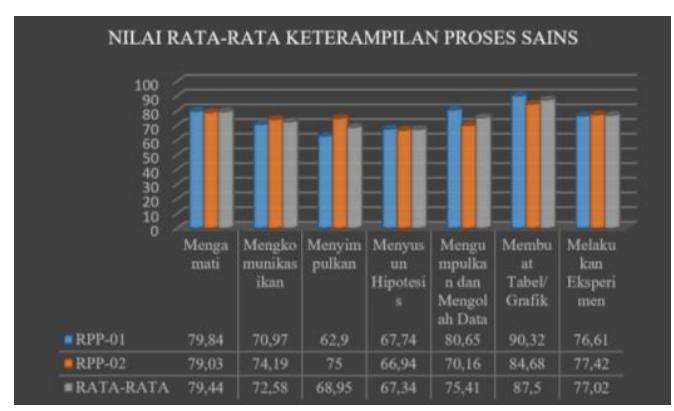

Gambar 1. Skor Keterampilan Proses Sains

Berdasarkan data pada gambar grafik di atas diperoleh rata-rata terendah adalah aspek menyusun hipotesis dengan nilai rata-rata sebesar 67,34 sedangkan aspek tertinggi adalah membuat tabel atau grafik dengan nilai rata-rata sebesar 87.50. Hal ini dikarenakan peserta didik begitu antusias pada saat melakukan praktikum secara langsung sehingga peserta didik dapat mengisi LKS dengan benar.

Selain itu, selama proses pembelajaran peserta didik dengan tekun memperhatikan permasalahan yang ada pada LKS melalui bantuan video pembelajaran. Mengingat selama disekolah peserta didik jarang sekali melakukan kegiatan praktikum atau eksperimen pada saat pembelajaran. Namun ketika peserta didik diminta untuk menyusun hipotesis tentang permasalahan yang ada di LKS mengenai praktikum yang akan dilakukan rata-rata peserta didik masih banyak yang kurang tepat dalam menjawab. Hal ini disebabkan banyak faktor yang mempengaruhi peserta didik diantaranya peserta didik kurang memperhatikan penjelasan dari peneliti yang berkaitan dengan praktikum yang akan dilakukan. Dalam hal ini peserta didik juga kurang memahami pertanyaan yang ada pada rumusan masalah. Terlihat bahwa peserta didik kurang mampu menjelaskan hipotesis penelitian yang diminta oleh peneliti yang terdapat didalam LKS.

Penilaian keterampilan proses sains dilakukan sebanyak dua kali, yaitu pada percobaan pertama tentang getaran harmonis bandul sederhana dan percobaan kedua tentang getaran harmonis pada pegas. Dari hasil penilaian kedua percobaan dapat diketahui bahwa dari percobaan pertama ke percobaan kedua mengalamai peningkatan sebesar 1.55 yaitu rata-rata yang semula 73.99 menjadi 75.54. Hal ini menunjukan bahwa semakin peserta didik terbiasa melakukan praktikum maka keterampilan proses sains peserta didik juga semakin bagus. Ratarata nilai keterampilan proses sains peserta didik secara klasikal adalah sebesar 75.50. Berdasarkan kriteria keterampilan proses sains, kategori nilai tersebut masuk dalam kategori diantara $75 \leq$ KPS $\leq 100$. Sehingga dapat dikatakan bahwa secara rata-rata keterampilan proses sains pada kelas eksperimen dengan menggunakan model Problem Based Learning (PBL) disertai video berbasis kontekstual berada dalam kategori sangat baik. 


\section{KESIMPULAN}

Berdasarkan hasil dan pembahasan pada bab sebelumnya dapat diperoleh kesimpulan sebagai berikut:

a. Model pembelajaran Problem Based Learning (PBL) disertai video berbasis kontekstual berpengaruh signifikan terhadap kompetensi pengetahuan peserta didik pada pembelajaran fisika kelas X SMA Negeri Tamanan.

b. Tingkat kemampuan keterampilan proses sains peserta didik melalui penerapan model pembelajaran Problem Based Learning (PBL) disertai video berbasis kontekstual meningkat pesat pada pembelajaran fisika kelas $\mathrm{X}$ di SMA Negeri Tamanan dan termasuk dalam kategori baik.

\section{DAFTAR PUSTAKA}

Eko, Febrian. 2012. Pengembangan Media Audio-Visual Berbasis Kontekstual dalam Pembelajaran Fisika di SMA. Jurnal Pembelajaran Fisika. ISSN 23019794. Vol. 1(3): 247-253

Puspendik Kemnedikbud. 2017. Laporan Hasil Ujian Nasional. [Online] Tersedia.

(http://puspendik.kemdikbud.go.id /hasil-un/), diakses 24 Maret 2019

Rusman. 2012. Model-Model Pembelajaran Mengembangkan Profesionalisme Guru (Edisi kedua). Jakarta: Raja Grafindo Persada.

Tirtarahardja, Umar. 2005. Pengantar Pendidikan. Jakarta: Penerbit Rineka Cipta

Trianto. 2010. Model Pembelajaran Terpadu: Konsep, Strategi dan Implementasinya dalam Kurikulum Tingkat Satuan Pendidikan (KTSP). Jakarta: Bumi Aksara.
Widayanto. 2009. Pengembangan

Ketrampilan Proses dan Pemahaman Siswa Kelas X Melalui Kit Optik. Jurnal Pendidikan Indonesia, Vol. 5, No. 1, Januari 2009. 